\title{
'Black like Me': A Critical Analysis of Arrest Practices Based on Skin Color in the Gauteng Province, South Africa
}

\author{
Nomsa Ingrid Zikalala, Jacob T. Mofokeng and Hendrick P. Motlalekgosi
}

\author{
Department of Safety and Security Management, Tshwane University of Technology, South Africa
}

\begin{abstract}
Objective: This article looks at the everyday life and realities of current practices employed by the South African Police Service (SAPS) officials, by shedding light on the experiences and practices on profiling search and effecting arrest based on race and skin color in the Gauteng Province. Particularly, this article examines the experiences of the SAPS officials to measure police perception of the skin color of foreign nationals, and to establish if wrongful arrests were linked to skin color stereotyping.

Methods: The theoretical approach employed the social identity theory (SIT) was used to interpret the results. A survey questionnaire consisting of the New Immigration Survey (NIS) Skin Color Scale with 10 shades of skin color mapped to a pictorial guide, as well as a self-report measure on wrongful arrests, was administered to 80 SAPS officials, who performed visible policing duties. The research sample consisted of two SAPS groups from two different contexts, namely township and urban contexts. The Statistical Package for the Social Sciences (SPSS) software was used to conduct Pearson's correlation and comparative analyses.

Results: The results showed that the SAPS officials stereotyped foreign nationals as dark-skinned. The skin color stereotype was, however, not correlated to wrongful arrests. The study concluded that although respondents perceived that South Africans were distinguishable from foreign nationals based on skin color or tone, identification processes were not influenced by this stereotype belief.
\end{abstract}

Keywords: Color, policing, profiling, racism, stereotype.

\section{INTRODUCTION}

In terms of Section 205(3) of the Constitution of the Republic of South Africa (1996), the South African Police Service (SAPS) has a legal obligation to uphold and enforce the law (South Africa 1996). This means that every enforceable law passed through the parliamentary legislative process is the responsibility of the SAPS. The South African Immigration Act 13 of 2002, as amended by Immigration Act 3 of 2007 and 13 of 2011, is one such law. Section 9 of this Act makes provision for the regulation of admission of documented foreign nationals into and their departure from the Republic. According to the Mid-year population estimates report for 2018 released by Statistics South Africa (SSA), the population of South Africa was estimated at 57,7 million as of 1 July 2018.

While births and deaths are considered the main drivers of population change, migration continues to be significant, not only demographically but politically, economically, and socially (SSA 2018). Gauteng Province has the highest proportion of foreign-born workers, numbering about $8 \%$ of the working population, followed by Limpopo and Mpumalanga at $4 \%$, while in the North West and Western Cape the figure stands at $3 \%$ (SSA 2018). Sokutu (2018)

*Address correspondence to this author at the Department of Safety and Security Management, Tshwane University of Technology, South Africa;

Tel: +27(0) 12382 9610; Fax: +27(0) 86274 4979;

E-mail: MotlalekgosiD@tut.ac.za reiterated the 2018 SSA report that over two million foreign nationals around 2018 were documented and close to one million undocumented.

The Mid-year population estimates report, also shows that South Africa is estimated to receive net immigration of 1,02 million people between 2016 and 2021. Most international migrants settle in Gauteng at $47,5 \%$ while the least are found in the Northern Cape province $(0,7 \%)$. Gauteng is considered the economic hub of the country, attracting international migrants as well as domestic migrants from rural provinces such as Limpopo, KwaZulu-Natal, and Eastern Cape (SSA 2018).

Although the police served the interest of the apartheid state, public accountability of the police should be understood within a broad social and historical context in which the police represented only one of many oppressive state structures (Howell 2019; Howell and Shearing 2017; Young 2004). According to Van der Westhuizen (2001) cited in Young (2004:19), the development and history of policing in South Africa need to be placed within the context of broader government racial policies whereby police work was defined primarily as the policing of race relations and policing became a political activity. Post-apartheid South Africa is emerging as a new country from years of rule-based solely on the color of one's skin. An important component of the new South Africa is the transformation of the SAPS. 
From a history of brutal and indiscriminate violence, the new police system is attempting to transition into a respectable democratic police organisation. The initial transformation began in 1994, soon after the fall of the apartheid government, and has continued until the present (Pruitt, 2010:116). With the abuses of apartheid-era policing still fresh in the minds of many citizens, the architects of South Africa's new constitution were careful to ensure that the police could be held accountable through several civilian-run structures and institutions. Nevertheless, a little over a decade of police reform in South Africa and concerns have been expressed that accountability and oversight have faded from the public agenda as the democratic government's control of the police has consolidated and as rising crime rates have instead come to dominate public and political concerns (Bruce and Neild, 2005:6).

Much of apartheid-era policing was reactive to protests and demonstrations. It became crucial for SAPS to be able to act proactively in a new democratic government. Building a relationship with the communities in which the officers worked was seen as the first step toward becoming Proactive (Pruitt 2010:120). Possibly the biggest change in the police was the smallest. During the reign of apartheid, the police were formally known as the South African Police (Morna 1995 cited in Pruitt 2010:121).

Following the fall of apartheid, the police have christened the SAPS. This change was meant to highlight the fact that the police are present to provide a service to the public and not act as a force upon them. President Mandela and most other new government officials urged the South African people to accept the new policy as their protectors (Gastrow and Shaw 2001 cited in Pruitt, 2010:121). The new name for the police was designed to increase that acceptance and encourage the new goal of community policing.

Brogden and Shearing (1993:93) point out that the introduction of new forms of policing never happens instantaneously, but always involves a process of transition: "In policing, as in other areas of social life, there is no clean slate. We seldom - perhaps fortunately - have an opportunity to work from scratch". This is particularly true of the SAPS where the transformation is from an authoritarian system to a system that has to be sensitive to the needs of many different constituencies (Bellinghan 1994 cited in Young 2004:19). As both a product of deeply traumatic history and the failure of the post-apartheid state to capitalise on the resources with which the country is endowed, South African society is itself fragmented, often troubled, and seemingly intersected by contradiction.

It is, for instance, a "nonracial", yet a racially defined society, one of the most economically unequal in the world and yet enshrines equality in the Constitution and one in which the oppression which characterised its history continues to define the contemporary (Howell and Shearing 2017). It is widely agreed that the police service needs to be reshaped to support and empower the community, but there are no packaged solutions that South Africans can simply embrace (Young 2004:19). Now that it has been a little over two decades since the birth of democracy in South Africa, it is appropriate to reflect on the continuing challenges facing police reform (Newham 2005:175).

In this article, the authors use the term 'black' specifically to refer to people of African heritage who are socially constructed or racialised as black in South Africa. Though of diverse historical, socio-cultural, and political backgrounds, they share a similar phenotypical appearance, notably their dark skin, and have connections with continental Africa (Mapedzahama and Kwansah-Aidoo 2017; Udah and Singh 2018). The bright colors of the rainbow nation signal hope to conflict-ridden countries around the world. South Africa is not an exception. However, the legacy of apartheid that shaped policing practices in South Africa, leaves a question that lingered on for years, whether the concept of democratic policing is a fact or an illusion, in the Gauteng Province, South Africa.

Contemporary South Africa remains the dominant country in sub-Saharan Africa, both economically (World Bank 2017 cited by Howell 2019:93). Despite this, it is also one of the most socially fractured and unequal (Howell 2019:93). Both as a function of its political history and as a result of numerous ongoing governance concerns, seemingly immaterial differences have become translated into deeply embedded structural forms of marginalisation. South Africa's predilection for racial distinctions is one such example.

Under the apartheid regime, five entirely artificial racial characterisations were invented to justify the systematic division of society, the result of which is that long after the fall of apartheid these racial distinctions are still manifested in the economic and social patterns which structure society and indeed the physical spaces 
of its urban areas. They remain, in short, predominantly in "black" townships, "colored" ghettos, small pockets of "Indian" areas, and "white" suburbs (Howell 2019:93).

Thus, this article reflects not only an attempt to understand and interrogate the subjective or stereotype practices by the SAPS officials but also a commitment to bringing about social change. This article focuses on the challenging issue of underlying racism and skin color (blackness) as an important, if not the most central, factor for consideration in assessing policing practices, as measured by profiling of black Africans in the Gauteng Province. This is because racial discrimination can make it more difficult for foreign nationals from culturally and linguistically diverse backgrounds to be accepted where they reside. This influence policing practices (Howell 2019; Udah and Singh 2018).

For black Africans in the Gauteng Province, their visible difference, based on physical appearance, skin color, and cultural attributes, can complicate their social acceptance (Ndhlovu 2013 cited in Udah and Singh 2018:23). Thus, critical to understanding the SAPS practices in Gauteng Province is an elicitation of ways in which the visibility of foreign nationals, in terms of difference from light skin and/or white South African, interacts with other societal factors to marginalise, exclude and disadvantage them.

\section{RESEARCH HYPOTHESES}

The following three research hypotheses guided this study:

H1: The SAPS officials performing patrol duties do not perceive foreign nationals as dark-skinned.

H2: The SAPS officials who perform patrol duties, stereotype foreign nationals as dark-skinned, have a high number of wrongful arrests compared to those who do not stereotype foreign nationals as darkskinned.

H3: There is a likelihood that the SAPS officials deployed in urban areas differ significantly with stereotyping of foreign nationals, as compared with those in township settings.

\section{CONCEPTUAL FRAMEWORK: IDENTITY, RACE AND RACIALISATION}

Identity is an important and sensitive issue for many foreign nationals' sense of citizenship and belonging
(Udah and Singh 2018:23). Tabar, Noble and Poynting (2010:10) argue that identities are not simply symbolic entities through which we represent ourselves and others. For Tabar et al. (2010:10), identity embodies practices of identification and adaptation and deploys particular kinds of resources (as shaped by an individual's classed, gendered, and racialised histories) through which individuals situate and position themselves in diverse social domains.

For this article, it is useful to examine identity construction, especially in both its avowed and ascribed dimensions. While avowed identity is subjectively enacted by people's sense and knowledge of their membership in the social group in which they feel comfortable, affiliated, and at ease, ascribed identity is assigned by others who seek to label individuals as members of a given group based on their imagined or presumed phenotypic appearance, physical characteristics, cultural traits (e.g. skin color, language, name, dress, religion) or other stereotypical associations (Udah 2018; Udah and Singh 2018).

Both identities are, of course, important for understanding intercultural communication, which takes place when individuals influenced by different cultural communities negotiate shared meanings in everyday interactions (Udah 2018; Udah and Singh 2018). Since social interactions are ipso facto relations of power, identity construction becomes a matter of social context and must be situated historically (Guenther, Pendaz and Songora-Makene 2011; Udah and Singh 2018).

Racial identity is referred to as the notion of being black, white, Asian, or Aboriginal (Clark 2008; Kusow 2006; Udah and Singh 2018). This is different from a black racialised identity, which is the political act of becoming black (Dei [1999] 2018). A person's racial identity is often signified through their skin color, which becomes a counterfactually specifiable informationbearing trait that can be used for inclusion or exclusion (Asante, Sekimoto and Brown 2016; Bhabha 1998). Taylor (2007) cited in Udah and Singh 2018:25) asserts that classical racialism led people to believe that nature had sorted individuals into distinct and hierarchically ranked types, each with its complement of physical, moral, and mental traits.

The social identity theory (SIT) was used to underpin this study. According to Austin and Worchel (1986:7), social identity consists of three major processes: social categorisation, social identity, and social comparison. Social identity is viewed as a 
portion of one's self-concept attained through perceived membership in a social group. An individual's need for categorisation and social comparison is related to the need to maintain high selfesteem (Turner, Brown and Tajfel, 1979:187).

Based on the SIT, people tend to classify themselves and others into various social categories, such as organisational membership, religious affiliation, gender, and age cohorts (Ashforth and Mael 1989:20). The SIT assumes that people show all kinds of 'group' behaviour, such as solidarity, within their groups and discrimination against out-groups as a part of the social identity process, intending to achieve positive selfesteem and self-enhancement (Trepte 2006:256).

Tewolde (2018), reflecting on the South African institutional practices, argues that the practices of asking people to tick their racial identity on various forms is one mechanism the state uses to organise society into racialised social systems. A rigid form of racial classification was the norm during the apartheid era. Four major categories were created: black, white, colored, and Indian. Despite the post-apartheid state's orientation towards non-racialism, the racial categories continue to feature on administrative forms. The rationale behind this is to redress race-based inequalities through affirmative action programmes. Notwithstanding this noble aim, society continues to be racialised and race thinking endures. State-sanctioned racialisation also affects refugees and immigrants when they are asked to select their race on official forms.

One of the problems facing immigrants in South Africa is to confront the reality of adapting to racialised identity categories and to find their place in the racial classification system. Most refugees and immigrants come from contexts where racial categories are absent and whose social classification systems and selfidentification habits are based on culture and ethnicity. Many first-generation foreign national, define ourselves in terms of identity categories found in our countries of origin (Tewolde 2018).

\section{RESEARCH METHODS}

The study was carried out using a descriptive research design. The study describes the opinion of the respondents concerning shedding light on the experiences and practices on profiling search and effecting arrest based on race and skin color in the Gauteng Province. Particularly, this article examines the experiences of the SAPS officials to measure police perception of the skin color of foreign nationals, and to establish if wrongful arrests were linked to skin color stereotyping. The sampling method adopted for this study was systematic random sampling.

Randomly selected the SAPS stations were requested to provide at least three references. Only the first name was selected from every three referrals or prospective respondents enlisted. The respondent was then invited to the study and was asked to give referrals to three police officials who have conducted patrols before. This procedure was continued until a total of 10 respondents were invited per station, thus 80 in total. The research sample consisted of 80 respondents. 34 from the City of Johannesburg and 40 from the township of Thembisa, Ekurhuleni Metropolitan municipality. Of the 80 sampled respondents, $(n=6 ; 5.4 \%)$, indicated that they did perform patrol duties. Therefore, these respondents could not be included in this study.

This study was conducted in Gauteng Province across two metropolitan municipalities, namely Ekurhuleni and Johannesburg. These selected policing areas, comprised eight police stations. The following characteristics formed the criteria for participation in the study: South African citizenship, adults above 18 years, not interns or trainees, having previous patrol experience, and a minimum education level of Grade 12. Data was collected through a questionnaire utilising the NIS Skin Color Scale, which ranges from 1 to 10 on a Likert scale as depicted in Figure 1 below.

The NIS Skin Color Scale was designed to be used for skin tone evaluation soon after physical contact with

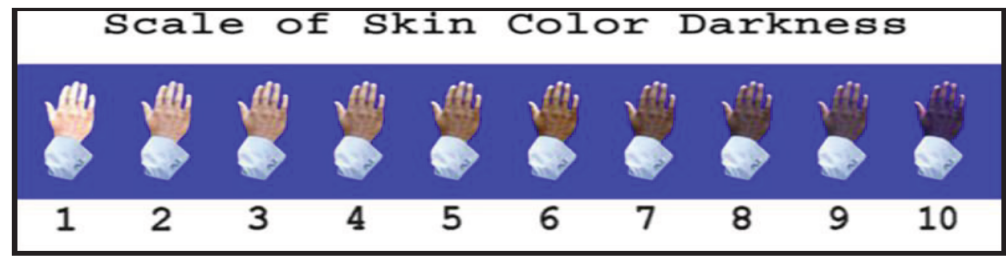

Figure 1: New Immigration Survey (NIS) Skin Color Scale.

(Massey and Martin 2003:2). 
an immigrant (Massey and Martin 2003:1). The scale has 10 shades of skin color mapped to a pictorial guide of male hands corresponding to points 1 to 10 (Hannon and DeFina [2016] 2020). This scale has been used in several high-profile social surveys but has not yet been psychometrically evaluated (Hannon and DeFina 2016:534). The NIS Skin Color Scale has not been tested in the South African context as it can be witnessed from a list of tests, which are classified and certified for use by persons registered in the profession of psychology as published by Professional Board for Psychology in terms of Health Professions Act 56 of 1974 regulations.

An independent t-test was conducted to establish if there were differences in the NIS mean scores of the two research groups. The t-test is an inferential statistical test andits purpose is to test for differences between the means of two groups (Terre Blanche, Durrheim and Painter 2006:211). Pearson's method was used to establish if there was a correlation between 'wrongful arrests and skin color perception' and 'in-group identification and skin color perception'. Pearson's correlation method in the Statistical Package for the Social Sciences (SPSS) was used to analyse the data.

\section{RESEARCH RESULTS}

\section{Demographic Information}

Males constituted seventy-six percent $(n=56$; $75.68 \%$ ) of respondents whereas female respondents were the least represented group by twenty-four percent $(n=18 ; 24.32 \%)$. This can be attributed to the history of the SAPS with only males being employed as police officials. It is also noted that worldwide trends show that fewer females than males consider policing as a profession (Aiello, 2019, Cambareri and Kuhns 2018; Gibbs 2019; Chan and Ho 2013; Helfgott, Gunnison, Murtagh and Navejar 2018; Rabe-Hemp 2009). A significant majority of respondents $(n=71$; 95.95\%) comprised of Africans, followed by Indians respondents who constituted three percent $(n=2 ; 2.7 \%)$ whereas one percent $(n=1 ; 1.35 \%)$ comprised of a White respondent. In terms of visual impairment, the majority of respondents $(n=54 ; 72.97 \%$ ), reported no visual impairment, followed by eighteen percent $(n=13$; $17.57 \%$ ) respondents who reported wearing glasses to read whereas, nine percent $(n=7 ; 9.46 \%)$ respondents, claimed wearing glasses to see people and things.

\section{In-Group Identification}

As shown in Table 1 below, the majority of the respondents $(n=45 ; 61 \%)$ indicated that they strongly identified with the SAPS. In terms of the SISI, the results implied that respondents were committed to the SAPS and they perceived the SAPS as an important part of how they saw themselves. Depending on the importance of group membership for the self-concept, group members differed in their level of identification with the group (Jetten, Spears and Manstead 1997:604). It has been shown by several studies that differences between high and low identifiers are only observed when identity is threatened. Furthermore, studies have shown that other factors such as cohesiveness of a group or the prototypicality of group members (Noel, Wann and Branscombe 1995) can moderate the strength of the relationship between ingroup bias and identification.

Identification has a moderation effect. Gabarrot and Falomir-Pichastor (2017:219) investigated the relationship between in-group identification and two indicators of intergroup differentiation-stereotyping and prejudice. The results indicated that the majority of respondents identified with their in-group, the higher their prejudice scores (Gabarrot and Falomir-Pichastor 2017:223). Based on these findings, it is argued that a respondents' level of identification (i.e. with the SAPS or being South African) might influence the respondents' level of prejudice and discrimination towards foreign nationals encountered during patrols.

\section{NIS Skin Color Scale Score}

Results on stereotype perceptions as depicted in Table 2 below, indicated that foreign nationals were

Table 1: In-Group Identification

\begin{tabular}{|c|c|c|c|c|c|c|c|c|c|}
\hline $\begin{array}{c}\text { In-group } \\
\text { identification }\end{array}$ & $\begin{array}{l}\text { Sample } \\
\text { size }\end{array}$ & $\begin{array}{l}\text { Strongly } \\
\text { disagree }\end{array}$ & $\begin{array}{c}\text { Slightly } \\
\text { disagree }\end{array}$ & $\begin{array}{c}\text { Neither agree } \\
\text { nor disagree }\end{array}$ & $\begin{array}{l}\text { Slightly } \\
\text { agree }\end{array}$ & Agree & $\begin{array}{l}\text { Strongly } \\
\text { agree }\end{array}$ & $\begin{array}{l}\text { Chi- } \\
\text { square }\end{array}$ & P-value \\
\hline $\begin{array}{l}\text { I identify with the } \\
\text { SAPS }\end{array}$ & $\mathrm{N}$ & 1 & 1 & 1 & 4 & 22 & 45 & 130.973 & $<.0001$ \\
\hline \multirow{2}{*}{$\begin{array}{l}\text { I identify with } \\
\text { being South } \\
\text { African }\end{array}$} & $\mathrm{N}$ & 0 & 0 & 1 & 1 & 18 & 54 & 101.2432 & $<.0001$ \\
\hline & $\%$ & 0 & 0 & 1.35 & 1.35 & 24.32 & 72.97 & - & - \\
\hline
\end{tabular}


Table 2: NIS Skin Color Scale Score

\begin{tabular}{|c|c|c|c|c|c|c|}
\hline Missing values & Mean & Std. deviation & \multicolumn{2}{|c|}{ 95\% CL mean } & \multirow{2}{*}{ T-value } & \multirow{2}{*}{ P-value } \\
\cline { 4 - 6 } & & & Thembisa & Johannesburg & \\
\hline \hline 2 & 7.4 & 1.9 & 7.0 & 7.9 & -353.4 & $<.0001$ \\
\hline
\end{tabular}

stereotyped as "dark-skinned" by both groups; in the township context NIS score $(\mathrm{M}=7.0)$ and the urban context NIS score $(M=7.9)$. The differences in NIS mean scores were interpreted with caution because the groups were small and differed in size. Based on the study findings, it can be safely argued that racial discrimination is still pervasive and deeply rooted in the Criminal Justice System (CJS), although it would be difficult to determine whether intentional discrimination of foreign nationals by the SAPS does still exist, as the empirical picture is more complex.

Lemon (2016) cited in Howell (2019:93) argues that post-apartheid South Africa remains bound to its history in innumerable ways. Indeed, the present context is built upon the design of difference formulated in the past, so much so that it is arguably very difficult to understand the contemporary subject matter without an understanding of how this history shapes both the subject and subjects found in the data. While often most powerful in the forms and practices that constitute the minutiae of daily interactions between people, this historical legacy is most visibly reinforced in the material structure of the cities. The findings highlighted that, there was a likelihood that the SAPS officials categorised foreign nationals as dark-skinned in contrast to South Africans.

Therefore, $\mathbf{H} 1$ (The SAPS officials performing patrol duties do not perceive foreign nationals as darkskinned) was rejected because the analysis found that the sample's mean NIS score was $7.4(\mathrm{~N}=74)$ and (SD $=1.9$ ). The implications are that, there is a likelihood, that darker-skinned individuals were more likely to experience an arrest than those with lighter skin, although the relationship between skin tone and arrest was moderated by gender within some racial/ethnic subgroups.

Specifically, darker skin tones were associated with adult arrests for black men, foreign nationals' men and women, as compared to other nationalities, women, and white men and white women. In line with the principle of categorisation, the findings implied that the sample perceived that a prototypical foreign national has NIS score 7 pigmentations. Overall, the findings of this study indicated skin tone was an important characteristic that affects the likelihood of experiencing an arrest of foreign nationals.

Based on group categorisation, when categorisation is salient, differences between social groups are accentuated (Trepte 2006:257). Locals and foreigners are two psychologically relevant categories (Leonardelli and Toh 2015). The findings also, highlighted that when the SAPS officials conducted patrol duties, it was easier for the officials to differentiate between these salient categories in the patrolling context, so the stereotype might have functioned to differentiate or distinguish South Africans from foreign nationals. Research indicates that social science research overall shows that racial discrimination does occur in some stages of justice processing, some of the time, and in some places, and that small differences in treatment accumulate across the CJS and over time, resulting in larger racially different outcomes (Rosich 2007:3).

The findings highlighted underlying stereotype threats that foreign nationals might have faced during their encounters with the SAPS. Racial stereotype threats have been evidenced in a South African policing context. The Minister of Finance, Honourable Tito Mboweni has spoken out about xenophobic police officers after his son was arrested and threatened with deportation for being too dark (Mbangeni 2013). Mathebula (2016) reported that the late Surprise Mazibila, who was a journalist with The Sowetan, was stopped by black police officers at Bree in central Johannesburg. He was singled out on a street with intensely congested pedestrian activity. The officers demanded a passport from this man, who was supposedly also "too dark" to be South African. Racial stereotypes have had behavioural consequences whereby the SAPS has wrongfully arrested South African citizens (and legal foreign nationals) as a result of stereotyping foreign nationals.

\section{Country-of-Birth Stereotype and Wrongful Arrest}

The comparative analysis results in Table 3 below showed that both research groups practised country-ofbirth stereotyping: Thembisa $(\mathrm{M}=2.6)$ and Johannesburg $(M=3.1)$. The differences between the 
Table 3: Country-of-Birth Stereotype

\begin{tabular}{|c|c|c|c|c|c|c|c|c|}
\hline \multirow{2}{*}{ Country } & \multirow{2}{*}{ Frequency } & \multirow{2}{*}{$\begin{array}{c}\text { Percentage } \\
\text { (\%) }\end{array}$} & \multirow{2}{*}{ Mean } & \multicolumn{2}{|c|}{$95 \%$ CL Mean } & \multirow{2}{*}{ T-value } & \multirow{2}{*}{$\begin{array}{c}\text { Std. } \\
\text { deviation }\end{array}$} & \multirow{2}{*}{$P$-value } \\
\hline & & & & Thembisa & Johannesburg & & & \\
\hline $\begin{array}{l}\text { 1. South } \\
\text { Africa }\end{array}$ & 7 & 9.5 & 2.8 & 2.6 & 3.1 & 21.6 & 1.126 & $<.0001$ \\
\hline 2. Tanzania & 31 & 41.9 & & & & & & \\
\hline 3. Zambia & 1 & 1.4 & & & & & & \\
\hline $\begin{array}{l}\text { 4. None of } \\
\text { the above }\end{array}$ & 34 & 45.9 & & & & & & \\
\hline Total & 73 & 98.6 & & & & & & \\
\hline Missing & 1 & 1.4 & & & & & & \\
\hline Total & 74 & 100.0 & & & & & & \\
\hline
\end{tabular}

mean scores were interpreted with caution owing to the unequal sizes of the groups.

The findings showed that only forty-six percent $(n=34 ; 45.9 \%)$ of respondents did not perceive the photos of the persons in the three identification document (ID) copies as non-South African. The respondents might have used other criteria besides skin color and country-of-birth stereotypes to identify persons. Coercive authority is central to the police role, and the discretionary use of police authority is a decision-making process, as officers evaluate the situations in which they intervene and choose a course of action from among a set of alternatives. This entry approaches the study of police discretion from this decision-making perspective.

It is concerned with several forms of authority such as stops, frisks and searches, arrests, tickets, and the use of physical force. Police authority is infrequently invoked, as a proportion of all police-citizen contacts. Officers consider their authority as a resource in "handling" situations, and often they can handle situations without resorting to the use of formal authority (Dymond 2019; Greer et al. 2020; Mastrofski et al. 2016). As demonstrated in Table 4 below, it was encouraging that a significant majority of respondents, $(n=73 ; 98.65 \%)$ indicated that they never wrongfully arrested anybody. The findings highlighted that one respondent $(n=1 ; 1.35 \%)$ wrongful arrested a foreign national. This was despite the high mean NIS score, which suggested that the respondents perceived that foreign nationals were dark-skinned.

Table 5 below shows that wrongful arrests and skin color stereotypes were not correlated. The findings are grounded in the social categorisation principle of the SIT. Stereotyping serves various functions as people categorise others in order to structure social interaction (Trepte 2006:257). The skin color stereotype belief might have enabled respondents to behave uniformly toward foreign nationals. Stereotypes enable individuals to act in an oversimplified, non-differentiated manner toward minority group members.

Therefore, based on the findings, H2 (The SAPS officials who perform patrol duties, stereotype foreign nationals as dark-skinned, have a high number of wrongful arrests compared to those who do not stereotype foreign nationals as dark-skinned). This hypothesis was rejected because no correlation was found between skin color stereotypes and wrongful arrests as depicted in Table 5 below.

Table 6 below depicts that in-group identification and skin color stereotype were not correlated. In terms of the social identity principle of the SIT, in-group identification accounts for intergroup behaviour. The results imply that other factors, except for in-group identification, accounted for the respondents' stereotyped perception. Based on the findings, H3 (There is a likelihood that the SAPS officials deployed

Table 4: Wrongful Arrests

\begin{tabular}{|c|c|c|c|c|}
\hline Wrongful arrests & More & Never & Chi-square & P-value \\
\hline $\mathrm{N}$ & 1 & 73 & 70.0541 & $<.0001$ \\
\hline$\%$ & 1.35 & 98.65 & & \\
\hline
\end{tabular}


Table 5: Wrongful Arrests and Skin Color Stereotype Correlational Analysis

\begin{tabular}{|c|c|c|}
\hline Statistical analysis & NIS mean-score & Wrongful arrests \\
\hline \hline Pearson correlation & 1 & .160 \\
\hline Sig. (one-tailed) & - & .090 \\
\hline N & 72 & 72 \\
\hline Pearson correlation & .160 & 1 \\
\hline Sig. (one-tailed) & .090 & - \\
\hline N & 72 & 74 \\
\hline
\end{tabular}

Table 6: Identification and Skin Color Stereotype Correlational Analysis

\begin{tabular}{|c|c|c|c|}
\hline Statistical analysis & NIS mean score & (a) I identify with the SAPS & (b) I identify with being South African \\
\hline \hline Pearson correlation & 1 & .020 & -.020 \\
\hline Sig. (one-tailed) & - & .434 & 732 \\
\hline N & 72 & 72 & $.531^{* *}$ \\
\hline Pearson correlation & .020 & 1 & .000 \\
\hline Sig. (one-tailed) & .434 & - & 74 \\
\hline N & 72 & $.531^{* *}$ & 1 \\
\hline Pearson correlation & -.020 & .000 & - \\
\hline Sig. (one-tailed) & .432 & 74 & 74 \\
\hline N & 72 & & \\
\hline
\end{tabular}

**. Correlation is significant at the 0.01 level (one-tailed).

in urban areas differ significantly with stereotyping of foreign nationals, as compared with those in township settings), was accepted because the mean NIS score of the Thembisa group was $7.0(n=40)$ and the mean NIS score of the Johannesburg group was $7.9(n=34)$.

\section{CONCLUSION}

The findings of this study, proved that foreign nationals were stereotyped as dark skinned in a police context. The perception that foreign nationals are dark skinned was apparent in both the urban and township police contexts, namely the city of Johannesburg and the township of Thembisa. This implied that respondents perceived that a prototypical foreign national is dark-skinned. The findings showed that skin color stereotypes were not correlated to wrongful arrests. The skin color stereotype might have been a useful criterion for distinguishing citizens from foreign nationals since the sample reported a low error in identification or comparatively few wrongful arrests. The study concluded that although respondents perceived that South Africans were distinguishable from foreign nationals based on skin color or tone, identification processes were not influenced by this stereotyped belief.

\section{REFERENCES}

Aiello, Michael Francis 2019. "Gendered Messages in Police Recruitment: Understanding the Impacts of Descriptors and Physical Fitness Requirements on Potential Applicants." Policing: An International Journal 42(3):455-73. https://doi.org/10.1108/PIJPSM-05-2018-0072

Asante, Godfried, Sachi Sekimoto and Christopher Brown. 2016 "Becoming "Black": Exploring the Racialized Experiences of African Immigrants in the United States." Howard Journal of Communications 27(4):367-84. https://doi.org/10.1080/10646175.2016.1206047

Ashforth, Blake and Fred Mael. 1989. "Social Identity Theory and the Organization." Academy of Management Review 14(1): 2039. https://doi.org/10.5465/amr.1989.4278999

Austin, William and Stephen Worchel. 1986. Psychology of Intergroup Relations. Chicago: Nelson-Hall Publishers

Bhabha, Homi. 1998. "The White Stuff: Political Aspect of Whiteness." Artforum International 36(9):21-23.

Brogden, Mike and Clifford Shearing. 1993. Policing for a new South Africa. London: Routledge.

Bruce, David and Neild, Rachel. 2005. The police that we want: $A$ handbook for oversight of police in South Africa. Johannesburg: Centre for the Study of Violence and Reconciliation.

Cambareri, Josie Francesca and Joseph B. Kuhns. 2018 "Perceptions and Perceived Challenges Associated With a 
Hypothetical Career in Law Enforcement: Differences Among Male and Female College Students." Police Quarterly 21(3): 335-57.

https://doi.org/10.1177/1098611118760862

Chan, Annie Hau-nung and Lawrence Ka-Ki Ho. 2013. "Women Police Officers in Hong Kong: Femininity and Policing in a Gendered Organization." Journal of Comparative Asian Development 12(3): 489-515. https://doi.org/10.1080/15339114.2013.863565

Clark, Msia Kibona. 2008. "Identity Among First and Second Generation African Immigrants in the United States." African Identities 6(2):169-81. https://doi.org/10.1080/14725840801933999

Dei, George J. Sefa. 1999. "The Denial of Difference: Reframing Anti-racist Praxis." Race, Ethinicity and Education 2: 17-21. https://doi.org/10.1080/1361332990020103

Dei, George J. Sefa. 2018. "Black Like Me': Reframing Blackness for Decolonial Politics." Educational Studies 54(2):117-42. https://doi.org/10.1080/00131946.2018.1427586

Dymond, Abi. 2019. "Towards a Socio-technical Understanding of Discretion: A Case Study of Taser and Police Use of Force." Policing and Society 30(9):998-1012. https://doi.org/10.1080/10439463.2019.1660338

Gabarrot, Fabrice and Juan Manuel Falomir-Pichastor. 2017. "Ingroup Identification Increases Differentiation In Response To Egalitarian Ingroup Norm Under Distinctiveness Threat." International Review of Social Psychology 30(1):219-28. https://doi.org/10.5334/irsp.22

Gibbs, Jennifer. 2019. "Diversifying the Police Applicant Pool: Motivations of Women and Minority Candidates Seeking Police employment." Criminal Justice Studies 32(3):207-21. https://doi.org/10.1080/1478601X.2019.1579717

Greer, Alissa, Justin Sorge, Marion Selfridge, Cecilia Benoit, Mikael Jansson and Scott Macdonald. 2020. "Police discretion to Charge Young People Who Use Drugs Prior to Cannabis Legalization in British Columbia, Canada: A Brief Report of Quantitative Findings." Drugs: Education, Prevention and Policy 27(6):488-93.

https://doi.org/10.1080/09687637.2020.1745757

Guenther, Katja, Sadie Pendaz, and Fortunata Songora-Makene. 2011. "The Impact of Intersecting Dimensions of Inequality and Identity on the Racial Status of Eastern African Immigrants." Sociological Forum 26(1): 98-120. https://doi.org/10.1111/j.1573-7861.2010.01226.x

Hannon, Lance \& Robert DeFina. 2020. "The Reliability of SameRace and Cross-Race Skin Tone Judgments." Race and Social Problems12: 186-94. https://doi.org/10.1007/s12552-020-09282-4

Hannon, Lance and Robert DeFina. 2016. "Reliability Concerns in Measuring Respondent Skin Tone by Interviewer Observation." Public Opinion Quarterly 80(2):534-41. https://doi.org/10.1093/pog/nfw015

Helfgott, Jacqueline, Elaine Gunnison, Autumn Murtagh and Bridgette Navejar. 2018. "'Badasses': The Rise of Women in Criminal Justice." Women \& Criminal Justice 28(4):235-61. https://doi.org/10.1080/08974454.2018.1468296

Howell, Simon and Clifford Shearing. 2017. "Prisons, Tourism and Symbolism: Reflecting (on) the Past, Present and Future of South Africa." Pp. 277-294 in The Palgrave Handbook of Prison Tourism, edited by J. Z. Wilson, S. Hodgkinson, J. Piché and K. Walby. London: Palgrave Macmillan. https://doi.org/10.1057/978-1-137-56135-0 14

Howell, Simon. 2019. "Description of the South African Context." Pp. 93- 106 in The Codes of the Street in Risky Neighborhoods: A Cross-Cultural Comparison of Youth Violence in Germany, Pakistan, and South Africa, edited by W. Heitmeyer, S. Howell, S. Kurtenbach, A. Rauf, M. Zaman and S. Zdun. Switzerland: Springer.

https://doi.org/10.1007/978-3-030-16287-0 8
Jetten, Jolanda, Russel Spears and Anthony Manstead. 1997. "Strength of Identification and Intergroup Differentiation: The Influence of Group Norms." European Journal of Social Psychology 27(5):603-09.

https://doi.org/10.1002/(SICl)1099 0992(199709/10)27:5<603::AID-EJSP816>3.0.CO;2-B

Kusow, Abdi. 2006. "Migration and Racial Formations Among Somali Immigrants in North America." Journal of Ethnic \& Migration Studies 32(3):533-51. https://doi.org/10.1080/13691830600555079

Leonardelli, Geoffrey and Soo Min Toh. 2015. Social Categorization in Intergroup Contexts: Three Kinds of Self-Categorization." Social and Personality Psychology Compass 9(2):69-87. https://doi.org/10.1111/spc3.12150

Mapedzahama, Virginia and Kwamena Kwansah-Aidoo. 2017. "Blackness as Burden? The Lived Experience of Black Africans in Australia." SAGE Open 7(3):1-13 https://doi.org/10.1177/2158244017720483

Massey Douglas and Martin Jennifer. 2003. The NIS Skin Color Scale. Princeton, NJ: Princeton University Press.

Mastrofski, Stephen, Tal Jonathan-Zamir, Shomron Moyal, and James Willis. 2016. "Predicting Procedural Justice in PoliceCitizen Encounters." Criminal Justice and Behavior 43(1):119-39. https://doi.org/10.1177/0093854815613540

Mathebula, Austil. 2016. "50 shades of black - SA, The Pigmentocracy," The Citizen, June 7, Retrieved April 6, 2019 (https://citizen.co.za/news/opinion/opinioncolumns/1141303/layers-of- blackness-is-sa-apigmentocracy/)

Mbangeni, Lerato. 2013. "Tito's son held for being 'too dark'," IOL, December 30, Retrieved March 2, 2019 (https://www.iol.co.za/news/titos-son-held-for-being-too-dark1627323).

Newham, Gareth. 2005. "Strengthening Democratic Policing in South Africa through Internal Systems for Officer Control." South African Review of Sociology 36(2):160-77. https://doi.org/10.1080/21528586.2005.10419136

Noble, Greg and Paul Tabar. 2014. "Learning To Be Lebanese: Fashioning an Ethnicised Habitus in Multicultural Australia." Pp. 15-26 in Palestinian, Lebanese and Syrian Communities in the World: Theoretical Frameworks and Empirical Studies, edited by T. Batrouney, T. Boos, A. Escher, \& P. Tabar. Heidelberg: Universitätsverlag Winter.

Noel, Jeffrey, Daniel Wann and Nyla Branscombe. 1995. "Peripheral Ingroup Membership Status and Public Negativity Toward Outgroups." Journal of Personality and Social Psychology 68(1):127-37. https://doi.org/10.1037/0022-3514.68.1.127

Pruitt, William. 2010. "The Progress of Democratic Policing in South Africa. African Journal of Criminology and Justice Studies 4(1):116-40.

Rabe-Hemp, Cara. 2009. POLICEwomen or PoliceWOMEN?: Doing Gender and Police Work. Feminist Criminology4(2 ):114-29. https://doi.org/10.1177/1557085108327659

Rosich, Katherine. 2007. Race, Ethnicity, and the Criminal Justice System. Washington, DC: American Sociological Association.

Showers, Fumilayo. 2015. "Being Black, Foreign and Woman: African Immigrant Identities In the United States. Ethnic and Racial Studies 38(10): 1815-1830. https://doi.org/10.1080/01419870.2015.1036763

Sokutu, Brian. 2018. "Gauteng is home to most foreigners in the country," The Citizen, July 13, Retrieved February 20, 2019 (https://citizen.co.za/news/south-africa/1977973/gauteng- ishome-to most-foreigners-in-the-country/)

Sokutu, Brian. 2018. "Gauteng is home to most foreigners in the country," The Citizen, July 13, Retrieved February 20, 2019 
South Africa. 1974. Health Professions Act 56 of 1974. Pretoria: Government Printer.

South Africa. 1996. Constitution of the Republic of South Africa, 1996. Pretoria: Government Printer.

South Africa. 2002. Immigration Act, No. 13 of 2002, Retrieved January 12, $2020 \quad$ (http://www.saflii.org/za/legis/ num_act/ia2002138.pdf.)

South Africa. 2005. Immigration Regulations of 2005, Retrieved August 21, $2019 \quad$ (http://www.refworld.org/docid/ 42cc05444.html.)

South Africa. 2007. Immigration Amendment Act, No. 3 of 2007. Pretoria: Government Printer.

South Africa. 2011. Immigration Amendment Act, No. 13 of 2011. Pretoria: Government Printer.

Statistics South Africa. 2018. Mid-year population estimates 2018, Retrieved September 2, 2019 (http://www.statssa. gov.za/?p=11341.)

Tabar, Paul, Greg Noble and Scott Poynting. 2010. On being Lebanese in Australia: Identity, racism and the ethnic field. Beirut: Lebanese American University Press.

Terre Blanche, Martin, Kevin Durrheim and Desmond Painter. 2006. Research in Practice: Applied Methods for the Social Sciences. Cape Town: Juta.
Tewolde Amanuel Isak. 2018. "Race identity policy is irrelevant to 'new South Africans," Mail and Gaurdian, September 27, Retrieved January 2019 (https://mg.co.za/article/2018-09-2700-race-identity-policy-is-irrelevant-to-new-south-africans/)

Trepte, Sabine. 2006. "Social Identity Theory." Pp. 255-271 in Psychology of entertainment, edited by J. Bryant and P. Vorderer. Mahwah: Lawrence Erlbaum Associates Publishers.

Turner, John Charles, Roger Brown and Henri Tajfel. 1979. "Social Comparison and Group Interest in Ingroup Favouritism." European Journal of Social Psychology 9(2):187-204. https://doi.org/10.1002/ejsp.2420090207

Udah, Hyacinth and Parlo Singh. 2018. "It Still Matters: The Role of Skin Color In the Everyday Life and Realities of Black African Migrants and Refugees in Australia." Australasian Review of African Studies 39(2):19- 47. https://doi.org/10.22160/22035184/ARAS-2018-39-2/19-47

Udah, Hyacinth. 2018. "'Not By Default Accepted': The African Experience of Othering and Being Othered In Australia. Journal of Asian and African Studies 53(3):384-400. https://doi.org/10.1177/0021909616686624

Young, Marna. 2004. "Exploring the meaning of trauma in the South African Police Service." PhD thesis, Department of Psychology, University of Pretoria.

Received on 02-12-2020

https://doi.org/10.6000/1929-4409.2021.10.76

(c) 2021 Zikalala et al.; Licensee Lifescience Global.

This is an open access article licensed under the terms of the Creative Commons Attribution Non-Commercial License (http://creativecommons.org/licenses/by-nc/3.0/) which permits unrestricted, non-commercial use, distribution and reproduction in any medium, provided the work is properly cited. 